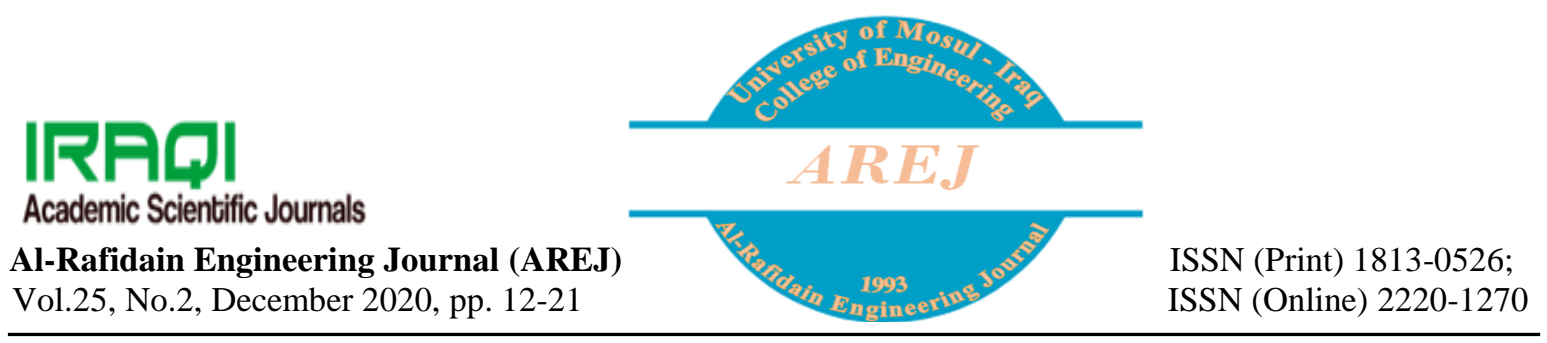

\title{
A Review on Mix Design of Self-Compacting Concrete
}

\author{
Nuha H. Aljubory \\ nuhahameedi.nh@uomosul.edu.iq
}

\author{
Tuqa Waleed Ahmed \\ new.matrix242@uomosul.edu.iq
}

Roua Suhail Zidan

rouasuhail@uomosul.edu.iq

Civil Engineering Department, Collage of Engineering, University of Mosul

Received: $2 / 3 / 2020$

Accepted: 27/7/2020

\begin{abstract}
In recent years, the use of self-compacting concrete in structures has increased significantly around the world Many studies have been carried out on the characteristics of this type of concrete with the urgent need to design concrete mix and to find the material ratios used in this type of concrete so far there are no standard mix design self-compacting concrete methods, but there are many types of research to design mixes. Hence the need to review and compare these methods is of considered interest. The review of these studies helps researchers to choose the appropriate method of designing the mixtures of self-compacting concrete and their requirements, whether the strength or workability requirements.
\end{abstract}

Keywords:

Self-compacting concrete; mix design; strength requirements; workability requirements.

https://rengj.mosuljournals.com

Email: alrafidain_engjournall@uomosul.edu.iq

\section{INTRODUCTION}

Self-compacting concrete SCC was developed firstly in Japan in 1988 [1]. It is a special type of concrete with high flowability and workability and resistance to segregation, this helps to fill the formwork and pass through the heavy reinforcement without using mechanical vibrations. The water/cement ratio and superplasticizer dosages were being one of the main key parameters in the proportioning of SCC mixtures [2]. SCC has a high performance and ability to flow and compact under its own weight without bleeding and segregation $[3,4]$. The curing conditions have a significant effect on the degree of hydration of cement and there are significant differences between conventional vibrated concrete and SCC especially during curing [5]. Some guidelines have been appointed to get mix proportions of self-compacting concrete consist of:

1- Reducing the ratio of aggregate volume to powder materials.
2- Reducing the content and the size of coarse aggregate particles and increasing the content of the fine particles.

3- Reducing water to powder ratio.

4- Using superplasticizer to reduce the water content and to get a high flowability.

Because of the low content of coarse aggregate, the elasticity modulus of self-compacting concrete was low compared to normal concrete, which affects the characteristics deformation of member and a high creep and shrinkage which increase long term deflection [6].

The mix design of self-compacting concrete comparison with conventional concrete required adding pozzolanic materials, superplasticizer dosages and sometimes, viscosity modifying agents $[7,8]$.

The factors affected the properties of SCC (strength, shrinkage, and durability) are the characteristic of the percentage of powder materials [9], superplasticizer, packing density, water to powder ratio, fine and coarse aggregate and methods of design $[10,11,12]$. 


\section{LITERATURE REVIEW}

The design of SCC according to the Japanese concept depends on a suggestion method by Okamura and Ozawa [13] in 1995. The authors had produced a simple system of mixproportioning assuming commonalty supply from the ready mixture concrete. The contents of fine and coarse aggregate are fixed then the water/powder ratio and the dosage of superplasticizer are adjusted to get selfcompatibility easily. The mixture design as proposed is:

- the content of coarse aggregate is specified as $50 \%$ of the total volume;

- the content of fine aggregate is specified as $40 \%$ of the mortar volume;

- assumed water/powder ratio in volume as 0.9 to 1.0 depending on the properties of the powder; and

- the dosage of superplasticizer and the final water/powder ratio are adjusted to get the selfcompatibility.

Domone et al. [14] in 1999 achieved the mortar properties of SCC by using four types of superplasticizers and different types of powders like pulverized fuel ash (PFA), Portland cement, limestone powder, ground granulated blast furnace slag (GGBS), and silica fume. The sand proportion was constant at $45 \%$ by volume. The water to cementitious material ratio was 0.945 and 1.26 by volume.

Bui et al.[15] in 2002 proposed a model depending on the rheological criteria of paste. Which depends on the volume of aggregate, the shape aggregate, the distribution of particle size of coarse and fine aggregates, the fine to coarse aggregate ratio, the surface characteristics of aggregate, the difference of density between the paste and aggregate, as depicted in Fig. (1). All procedure of mix design is shown in Fig. (2).

Okamura's method [13] was improved by Edamatsu et al.[16] in 2003 by limiting the water to powder ratio, the superplasticizer dosage, and the fine aggregate ratio. This method used aggregates and cementitious materials of different qualities.

Su and Miao [17] suggested a mix design method as shown in Fig. (3). In this method, low content of cement was used to get a flowing concrete with medium strength. First determining the packing factor, the workability was achieved by filling the void between the aggregate with GGBS and fly ash the paste volumes were $290-320 \mathrm{~L} / \mathrm{m}^{3}$ to obtain medium strength concretes. This method produced an eco-friendly and economical flowing concrete with low cement content $200 \mathrm{~kg} / \mathrm{m}^{3}$.

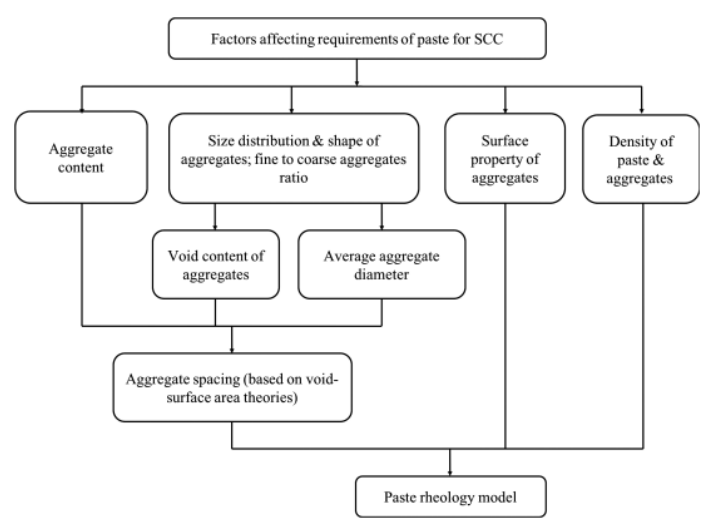

Fig. (1) Factors affecting the requirements of paste for SCC [15].

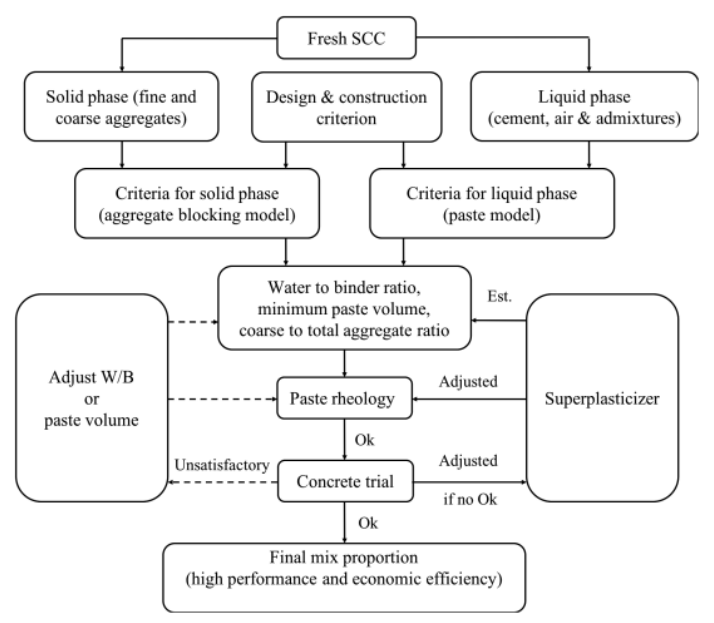

Fig. (2) Mix design procedure of SCC [15].

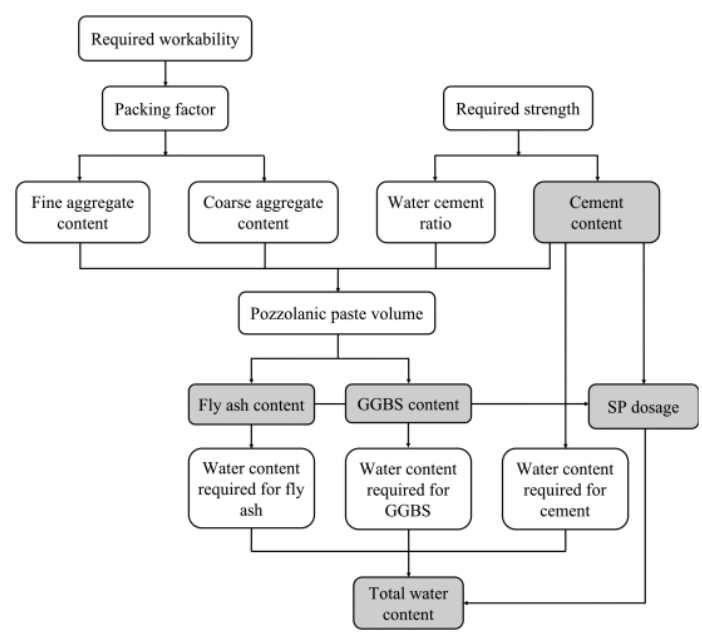

Fig. (3) Flowchart mix design of SCC [17].

Hwang and Hung [18] suggested a lightweight concrete mix design method as shown in Fig. (4), it used a densified mixture design algorithm 
(DMDA) to design lightweight SCC, there were two phases, aggregate phase and paste phase. The lightweight coarse aggregate, fine aggregate (normal weight), and fly ash represent the aggregate phase, whereas cement, slag, superplasticizer, and water represent the paste phase. The algorithm of (DMDA) is to minimize the porosity $(\mathrm{Vv})$ by filling the porosity between the coarse particles with fine particles. The concrete workability was attained by filling pores and lubricating. The hardened characteristics based on cement paste and lightweight aggregate properties. The result of workability showed that the SCLWC (self-compacting lightweight concrete) achieved a good flowability and high strength and durability by using the DMDA method.

Aggarwal et al. [19] in 2008 presented a selfcompacting concrete mix design of experimental procedure. The results of workability tests to get characteristics of self-compacting concrete like Jring, slump flow, L-Box, and V-funnel are presented. Further, compressive strength was determined at 7, 28, and 90 days. Different trial mixes were adopted. The content of coarse aggregates is 50 percent of total concrete by volume and the contents of fine aggregates are 40 percent of mortar in concrete by volume and variation in water to cement ratio and superplasticizer was carried out to attain SCC mixes. In the case of further trials, the content of coarse and fine aggregate was varied with variation in water to cement ratio to achieve the characteristics of SSC.

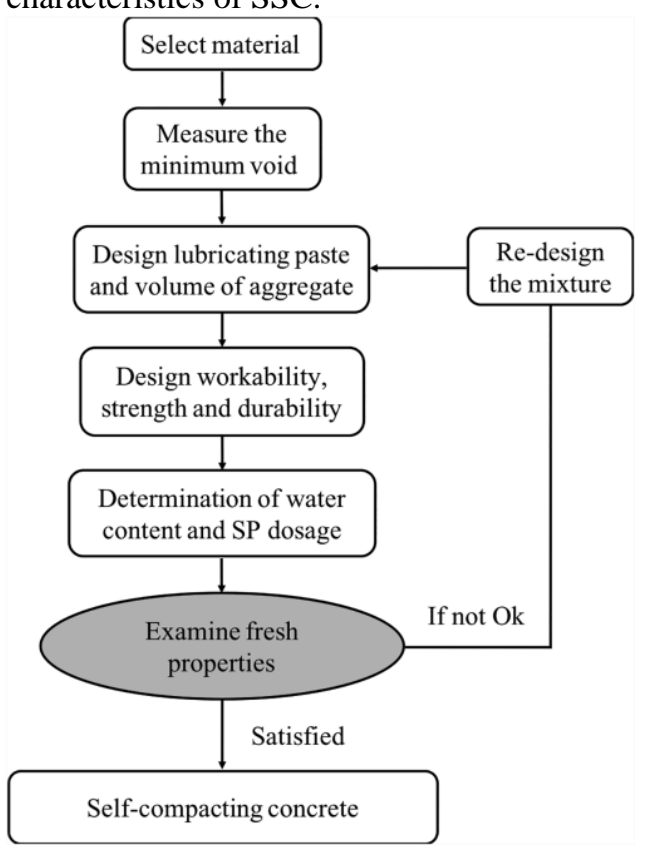

Fig. (4) Mix design procedure of SCC [18].
Domone [20] suggested the UCL method for the mix design of SCC, shown in Fig. (5). A trial mixes were used to evaluate the dosage of superplasticizer and the water to powder ratio and test the workability by The flow and V-funnel tests.

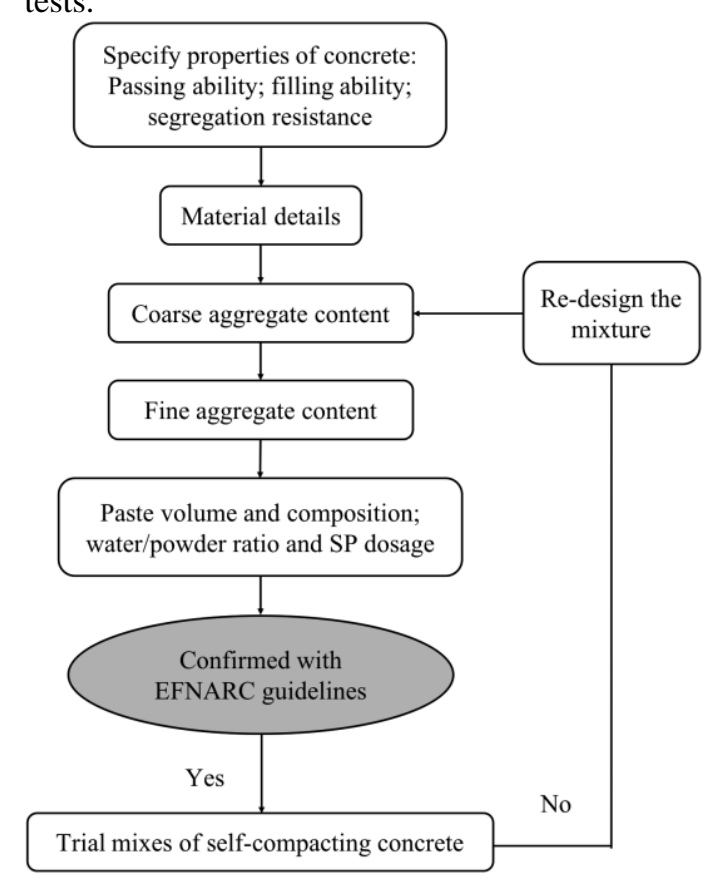

Fig. (5) Mix design procedure of SCC [20].

Kheder and Al-Jadiri [21] proposed a mix design method for SCC illustrated in Fig (6). The new method concentrated on compressive strength. In this method, two mix proportions were used. The first method was ACI 211.1 [22] for normal concrete and the second method was EFNARC [23] methods for SCC. These methods were combined with certain modifications, in the present method the strengths range was from 15 to $75 \mathrm{MPa}$ with w/c ratios from 0.80 to 0.29 respectively. The required compressive strength was obtained by specifying the water to powder ratios.

Dinakar [24] in 2012 was the first who proposed a methodology for designing the self- compacting concrete containing the fly ash for determinant strength and different replacement ratios for the fly ash. The methodology concluded that the replacement of $70 \%$ produced $30 \mathrm{MPa}$ and $30 \%$ produced $90 \mathrm{MPa}$ self-compacting concrete strength.

Jawahar et al. [25] in 2012 proposed a simple tool to design self-compacting concrete (SCC) mixture, this tool evaluated with a SCC mix having $28 \%$ of the content of coarse aggregate, class F fly ash of $35 \%$ replacement of cement, water/binder ratio is 0.36 by weight and volume 
of paste is 388 liter $/ \mathrm{m} 3$. The size of crushed granite stones is $20 \mathrm{~mm}$ and $10 \mathrm{~mm}$ are to be used with 60:40 a blending by percentage weight of total coarse aggregate.

The steps for designing concrete mixtures were as follows:

* The content of the air is assumed based on a percentage of the volume of the concrete. * The coarse aggregate blending took as a percent of the total weight of the coarse aggregate. * The volume of the coarse aggregate from the total volume of the concrete is calculated by the percentage of the dry-rodded unit weight of coarse aggregate.

* The percentage of fine aggregate is adjusted from the volume of mortar and then the volume of the paste and water/ binder ratio is found. * The replacement percent by weight of fly ash is entered from cementitious material. * The doses of the superplasticizer is calculated as a percentage of binder weight.

* The binder content is adjusted to get the paste requirement.

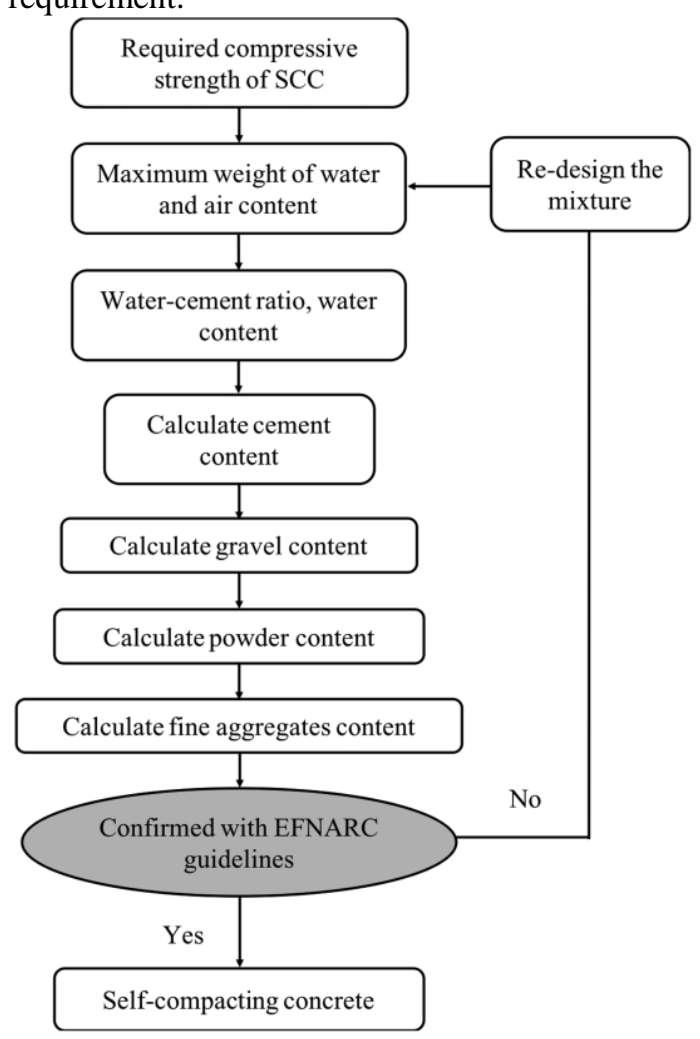

Fig. (6) Mix design procedure of SCC [21].

Dinakar et al. [26] in 2013 suggested a mix design of SCC by using a powder material from ground granulated blast furnace slag (GGBS), which illustrated in Fig. (7) and can be summarized in the following steps:

First step: the total powder content is fixed for SCC,
Second Step: the percentage of slag (GGBS Ground granulated blast furnace slag ) is Fixed and the efficiency of slag is calculated,

Third Step: calculate the water content of SCC.

Fourth Step: determine the fine and coarse aggregate contents,

Fifth step: calculate the dosage of superplasticizer (SP),

Sixth Step: a trial mix is adopted and test the fresh properties of SCC,

Seventh Step: the mixture proportions are adjusted.

It was noticed that the levels of replacement range from $20 \%$ to $80 \%$, gives a range of strengths from 30 to $100 \mathrm{MPa}$. When the replacements of GGBS reached $80 \%$, at 90 Days verified the same results of normal concrete after 28 days. However, the strength at 7 days of SCC was lower when compared with normal concrete.

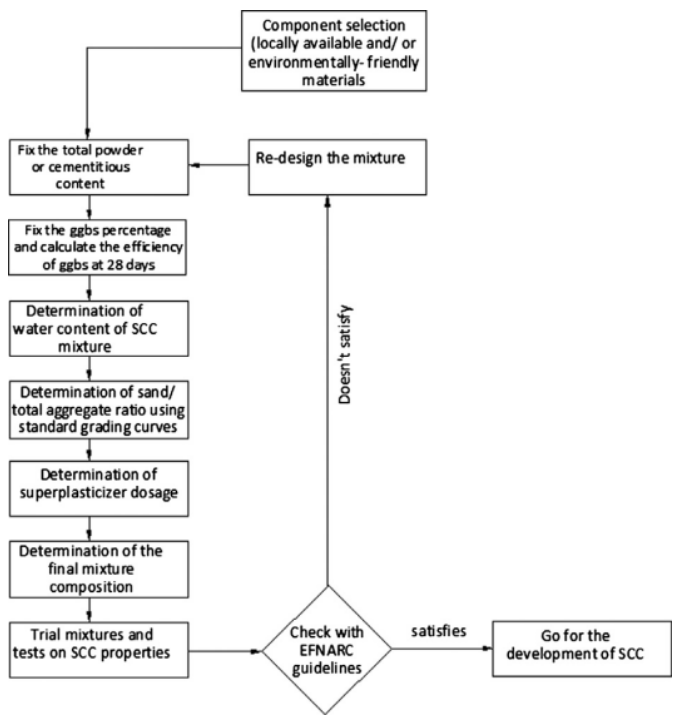

Fig. (7) Mix design procedure of SCC [26].

Deeb and Karihaloo [27] in 2013 suggested a variant method depending on computational simulations of mix proportioning of high performance and ultra-high performance SCC with and without steel fibers. The aggregates that used in conventional methods weren't used in the suggested method. Silica fume used in high performance SCC to improve the workability, the dosage of superplasticizer was increased and water to powder ratio was decreased to 0.23 .

The range of compressive strength was $35 \mathrm{MPa}$ to $160 \mathrm{MPa}$.

Kanadasan and Razak [28] in 2014 proposed a mix design method depending on the concept of particle packing as shown in Fig. (8). The SCC that contained palm oil clinker (POC) aggregate which also used as a binder; achieved the 
hardened properties and workability. The fresh requirements of SCC of EFNARC [23] were satisfied by this mix design. The promotes sustainability and natural resources were preserved when the waste materials used.

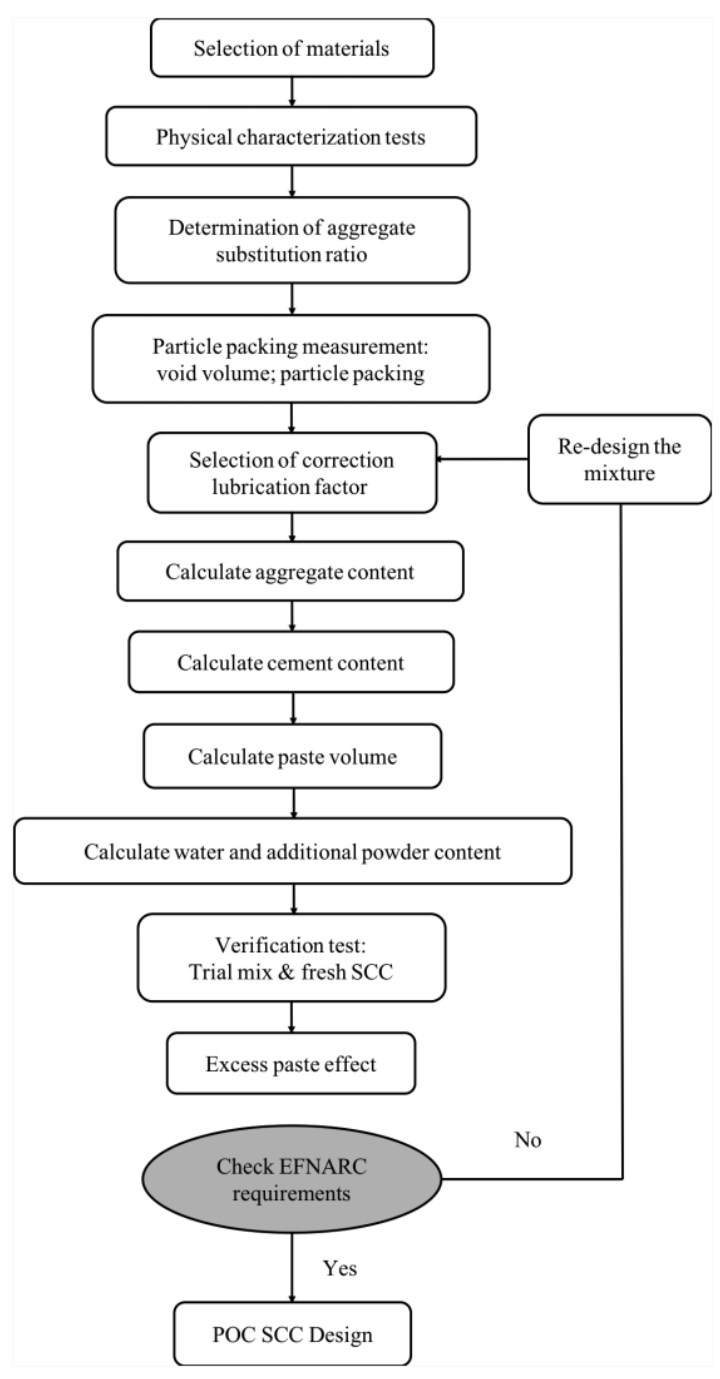

Fig. (8) Mix design procedure of SCC [28].

Dinakar and Manu [29] in 2014 suggested a methodology which depends on easy calculations as shown in Fig. (9). It can be obtained in 5 steps. In Step 1, the full powder content is installed. Step 2, then dependence on the requirements of strength, the metakaolin percentage, and the factor of efficiency $(\mathrm{K})$ are specified. In Step 3, the water content that was required for the selfcompacting concrete is determined, and in Step 4 the quantity of fine and coarse aggregate is found by utilization the curve of aggregate grading of DIN standards [30]. And finally, the properties of soft concrete are found through the test of flowability by V-funnel and the slump flow, and the ability of passing by L-Box. The selfcompacting concrete that designed by using the suggested methodology gets the strength that was expected (80, 100 and $120 \mathrm{MPa}$ ) and by proportions of metakaolin $(7.5 \%, 15 \%, 22.5 \%)$ with $550 \mathrm{~kg} / \mathrm{m} 3$ powder contents.

Kunar [31] in 2015 studied the design of concrete mixtures of self-compacting concrete by taking some trial mixtures. Fine and coarse aggregate content has been identified, self-compacting capability can be easily obtained by modifying the water to powder materials ratio and the doses of the superplasticizer. In traditional concrete, the ratio of water to cement is constant to obtain the required strength. In self-compacting concrete, the strength is not controlled by this ratio because it is low enough to obtain the required strength. The research concluded that there is no specific way to design self-compacting concrete but to adopt trial mixes obtained from the design methods of traditional concrete and adapted to get self-compacting concrete.

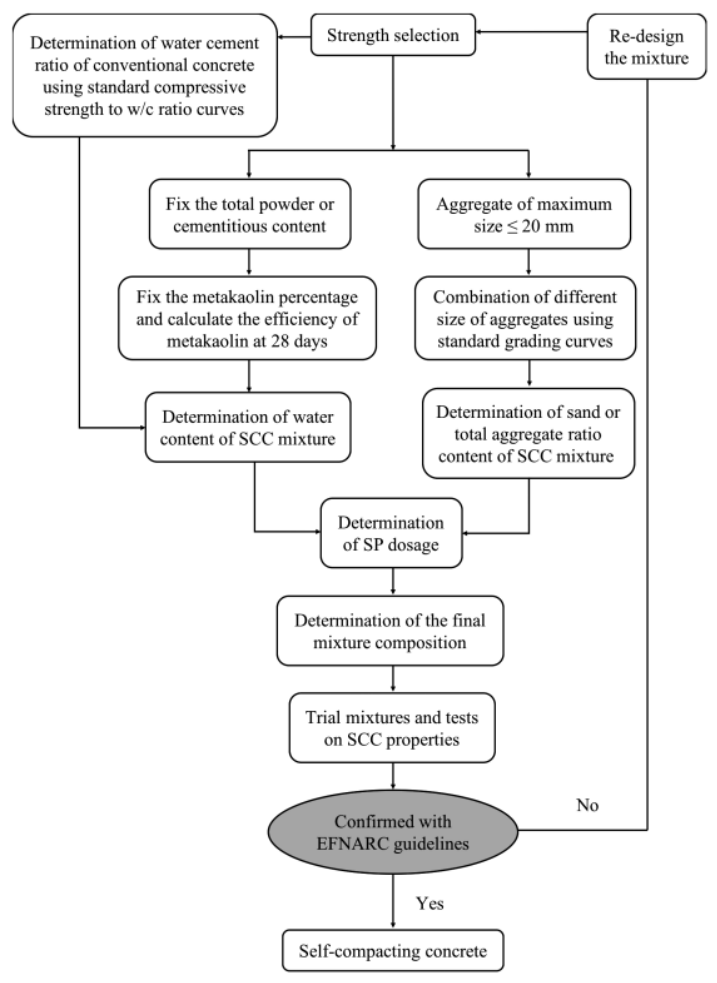

Fig. (9) Mix design procedure of SCC [29].

Ahlawat et al. [32] proposed SCC mix design. The fine and coarse aggregate content were adjusting so that the fine aggregate is about (5060) $\%$ of the total aggregate with or without viscosity modifying agent, when using superplasticizer the water content was reduced, the coarse aggregate size was controlled the 
results of L-Box so that when the size of aggregate was greater the flowability was less through the heavy reinforcement.

Indu and Elangovan [33] in the paper used SYSTAT software to find out an optimum proportional mix of self compacted concrete with high strength for different grades (30MPa $80 \mathrm{MPa})$. Several trial mixes were adopted including Fly Ash as mineral admixtures. The strength was increased when the water-cement ratio was reduced and adding the mineral admixture. Also by using chemical admixtures, the workability was improved and the segregation was minimized. After casting the compressive strength, flexural strength and split tensile strength at 1, 7, 14, 28, 56 and 90th days respectively are tested. From the results, an empirical relationship was obtained by using SYSTAT software. Hence for any assumed mix proportion of SCC can predict the strength with $90 \%$ to $95 \%$ accuracy.

Dhaheer et al. [34] proposed a simple mix design method for SCC. The design charts are dependent on rheological properties typified by compressive strength targeted and concrete plastic viscosity.

Thejas et al. [35] used MATLAB to formulate the relationships between input variables like the volume of paste, water-cement ratio, cement content, water content, and water-powder content and output parameters like compressive strength at 7, 28, 60 and 90 days, slump flow, L-box, Vfunnel, U-box, and J-ring. The experimental results from many literature surveys were used.

Ismail and Shahidan [36] proposed a simple mix design method that depended on a volumetric ratio to calculate amounts of materials; cement, aggregate, sand, and ADW (Asphalt Dust Waste ) by percentage from the required of total volume. The cement content in each mix was fixing $25 \%$ of the total volume. The amounts of granular varying with 0.3 water to binder ratio and $2 \%$ superplasticizer. The flowchart of mix proportion and the volumetric mix design is shown in Fig. (10).

In India no certain mix design process is adopted, SCC mix design procedure was investigated by Basu et al. [37] according to Indian Standard Code IS: 10262 [38] and Indian Standard Code of Reinforced Concrete Structure IS: 456 [39], a trial mix was adopted to get a SCC then testing the fresh concrete when the results were accepted then casting the final specimen to check the mechanical properties, compressive strength, flexure strength and splitting tensile strength and durability properties and microstructure properties. The flowchart in Fig. (11) shows the process of mix design.

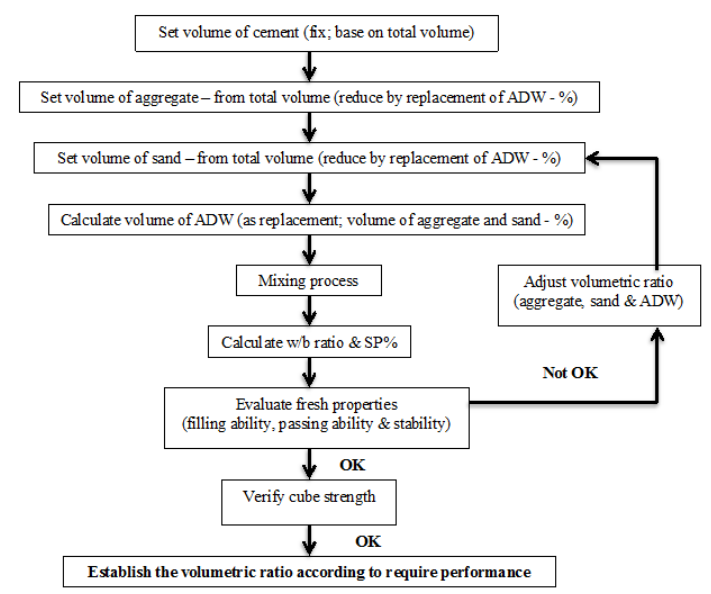

Fig. (10) Mix design procedure of SCC [36].

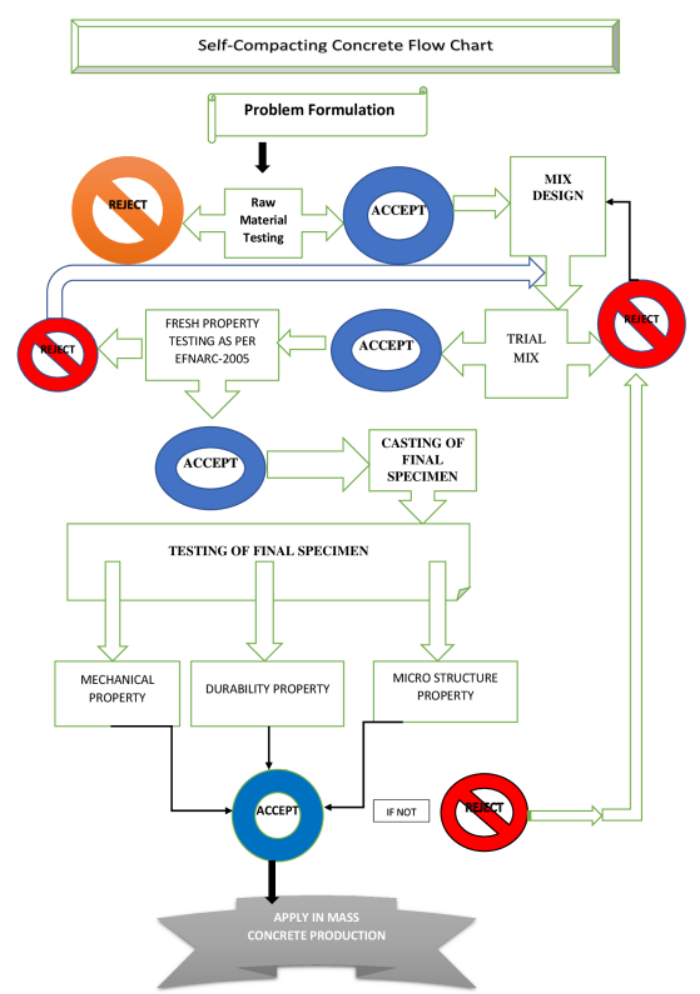

Fig. (11) Mix design procedure of SCC [37].

A comparison for the previous studies can be summarized as shown in Table (1).

Table (1) Comparison of the studies.

\begin{tabular}{|l|l|}
\hline $\begin{array}{l}\text { Authors, } \\
\text { year }\end{array}$ & summary \\
\hline Okamura & The contents of fine and coarse \\
\hline
\end{tabular}




\begin{tabular}{|c|c|}
\hline $\begin{array}{l}\text { and } \\
\text { Ozawa[13], } \\
1995\end{array}$ & $\begin{array}{l}\text { aggregate are fixed then the } \\
\text { water/powder ratio and the dosage } \\
\text { of superplasticizer are adjusted to } \\
\text { get self compatibility easily. }\end{array}$ \\
\hline $\begin{array}{l}\text { Domone et } \\
\text { al. } \quad[14], \\
1999\end{array}$ & $\begin{array}{l}\text { The sand proportion was constant } \\
\text { at } 45 \% \text { by volume. The water to } \\
\text { cementitious material ratio was } \\
0.945 \text { and } 1.26 \text { by volume. }\end{array}$ \\
\hline $\begin{array}{l}\text { Edamatsu } \\
\text { et al.[16], } \\
2003\end{array}$ & $\begin{array}{l}\text { Improved Okamura's method [13] } \\
\text { by limiting the water to powder } \\
\text { ratio, the superplasticizer dosage, } \\
\text { and the fine aggregate ratio. }\end{array}$ \\
\hline $\begin{array}{l}\mathrm{Su} \quad \text { and } \\
\mathrm{Miao}[17] \\
2003\end{array}$ & $\begin{array}{l}\text { Low content of cement was used } \\
\text { to get a flowing concrete with } \\
\text { medium strength. the paste } \\
\text { volumes were } 290-320 \mathrm{~L} / \mathrm{m}^{3} \text {. }\end{array}$ \\
\hline $\begin{array}{l}\text { Hwang and } \\
\text { Hung [18], } \\
2005\end{array}$ & $\begin{array}{l}\text { Design (SCLWC) self compacting } \\
\text { lightweight concrete by using } \\
\text { lightweight coarse aggregate. }\end{array}$ \\
\hline $\begin{array}{l}\text { Aggarwal } \\
\text { et al. [19], } \\
2008\end{array}$ & $\begin{array}{l}\text { The content of coarse aggregate is } \\
50 \text { percent of total concrete by } \\
\text { volume and the contents of fine } \\
\text { aggregate are } 40 \text { percent of mortar } \\
\text { in concrete by volume and } \\
\text { variation in water to cement ratio } \\
\text { and superplasticizer was carried } \\
\text { out to attain SCC mixes. }\end{array}$ \\
\hline $\begin{array}{l}\text { Domone } \\
{[20], 2009}\end{array}$ & $\begin{array}{l}\text { A trial mixes were used to } \\
\text { evaluate the dosage } \\
\text { superplasticizer and the water to } \\
\text { powder ratio. } \\
\end{array}$ \\
\hline $\begin{array}{l}\text { Kheder and } \\
\text { Al-Jadiri } \\
{[21], 2010}\end{array}$ & $\begin{array}{l}\text { The strengths range was from } 15 \\
\text { to } 75 \mathrm{MPa} \text { with w/c ratios from } \\
0.80 \text { to } 0.29 \text { respectively. The } \\
\text { required compressive strength was } \\
\text { obtained by specifying the water to } \\
\text { powder ratios. }\end{array}$ \\
\hline $\begin{array}{l}\text { Jawahar et } \\
\text { al. } \\
2012\end{array}$ & $\begin{array}{l}\text { SCC mix having } 28 \% \text { of the } \\
\text { content of coarse aggregate, class } \\
\mathrm{F} \text { fly ash of } 35 \% \text { replacement of } \\
\text { cement, water/binder ratio is } 0.36 \\
\text { by weight and volume of paste is } \\
388 \text { liter } / \mathrm{m}^{3} \text {. }\end{array}$ \\
\hline $\begin{array}{l}\text { Dinakar et } \\
\text { al. [26], } \\
2013\end{array}$ & $\begin{array}{l}\text { The total powder content and the } \\
\text { percentage of slag (GGBS) were } \\
\text { fixed, the water content of SCC } \\
\text { and the fine \& coarse aggregate } \\
\text { contents were determined and the } \\
\text { dosage of superplasticizer (SP) } \\
\text { was calculated. }\end{array}$ \\
\hline $\begin{array}{l}\text { Deeb and } \\
\text { Karihaloo } \\
{[27], 2013}\end{array}$ & $\begin{array}{l}\text { Silica fume used in high } \\
\text { performance SCC to improve } \\
\text { workability. The dosage of } \\
\text { superplasticizer was increased and } \\
\text { water to powder ratio was } \\
\text { decreased to } 0.23 \text {. }\end{array}$ \\
\hline
\end{tabular}

\begin{tabular}{|c|c|}
\hline $\begin{array}{l}\text { Dinakar } \\
\text { and Manu } \\
\text { [29], } 2014\end{array}$ & $\begin{array}{l}\text { The full powder content is } 550 \\
\mathrm{~kg} / \mathrm{m}^{3} \text {. The water content that was } \\
\text { required for the self-compacting } \\
\text { concrete is determined, the } \\
\text { quantity of fine and coarse } \\
\text { aggregate is found by utilization } \\
\text { the curve of aggregate grading of } \\
\text { DIN standards [30]. }\end{array}$ \\
\hline $\begin{array}{l}\text { Kunar } \\
2015\end{array}$ & $\begin{array}{l}\text { Fine and coarse aggregate content } \\
\text { has been identified. Self- } \\
\text { compacting capability can be } \\
\text { easily obtained by modifying the } \\
\text { water to powder materials ratio } \\
\text { and the doses of the } \\
\text { superplasticizer. }\end{array}$ \\
\hline $\begin{array}{l}\text { Ahlawat et } \\
\text { al. [32], } \\
2015\end{array}$ & $\begin{array}{l}\text { The fine and coarse aggregate } \\
\text { contents were adjusted, the fine } \\
\text { aggregate is about (50-60) \% of } \\
\text { the total aggregate with or without } \\
\text { viscosity modifying agent when } \\
\text { using superplasticizer the water } \\
\text { content was reduced. }\end{array}$ \\
\hline $\begin{array}{l}\text { Indu and } \\
\text { Elangovan } \\
{[33], 2016}\end{array}$ & $\begin{array}{l}\text { SYSTAT software used to find out } \\
\text { an optimum proportional mix of } \\
\text { self compacted concrete with high } \\
\text { strength for different grades } \\
(30 \mathrm{MPa}-80 \mathrm{MPa}) \text {. }\end{array}$ \\
\hline $\begin{array}{l}\text { Thejas et } \\
\text { al. [35], } \\
2017\end{array}$ & $\begin{array}{l}\text { MATLAB used to formulate the } \\
\text { relationships between input } \\
\text { variables like the volume of paste, } \\
\text { water-cement ratio, cement } \\
\text { content, water content, and water- } \\
\text { powder content and output } \\
\text { parameters like compressive } \\
\text { strength at } 7,28,60 \text { and } 90 \text { days, } \\
\text { slump flow, L-box, V-funnel, U- } \\
\text { box, and J-ring. }\end{array}$ \\
\hline $\begin{array}{l}\text { Ismail and } \\
\text { Shahidan } \\
{[36], 2017}\end{array}$ & $\begin{array}{l}\text { The cement content in each mix } \\
\text { was fixing } 25 \% \text { of the total } \\
\text { volume. The amounts of granular } \\
\text { varying with } 0.3 \text { water to binder } \\
\text { ratio and } 2 \% \text { superplasticizer. }\end{array}$ \\
\hline $\begin{array}{l}\text { Basu et al. } \\
\text { [37], 2018 }\end{array}$ & $\begin{array}{l}\text { According to Indian Standard } \\
\text { Code IS: } 10262 \text { [38] and Indian } \\
\text { Standard Code of Reinforced } \\
\text { Concrete Structure IS: } 456 \text { [39], a } \\
\text { trial mix was adopted to get a SCC } \\
\text { then testing the fresh concrete }\end{array}$ \\
\hline
\end{tabular}




\section{DISCUSSIONS}

Through a review of self compacting concrete mix design researches and studies, it can be noted that the following elements must be implemented; the mix design principles, the initial mix composition and the adjustment of the mix.

\subsection{MixDesignPrinciples}

1- Choosing the right method for designing mixtures of SCC depends on the desired requirements whether they are strength requirements or workability requirements and also depends on the type of powder materials and their chemical properties.

2- Trial mixes must be made in all methods to achieve the workability requirements set out in EFNARC [23].

3- Reducing the content of coarse aggregate in most researches to obtain the required workability and to prevent segregation. 4- Increasing powder materials to reduce spaces around coarse aggregate and get flowability of self compacting concrete.

5- Reducing water content by reducing the amount of water to powder ratios and this at the same time requires increasing superplasticizer dosages to obtain the required workability.

\subsection{Initial Mix Composition:}

It is most useful in the mix design to consider the relative proportions of the key components by volume rather than by mass.

1- Total powder content; 160 to 240 litres $/ \mathrm{m}^{3}$ $\left(400-600 \mathrm{~kg} / \mathrm{m}^{3}\right)$.

2- Water/cement ratio; typically water content does not exceed 200 litre $/ \mathrm{m}^{3}$.

3 - Water/powder ratio by volume of 0.80 to 1.10 .

4- Coarse aggregate content; normally 28 to 35 percent by volume of the mix.

5- The sand content balances the volume of the other constituents.

\subsection{Adjustment of the mix}

Laboratory trials mix must be used to check the properties of the initial composition of the mixture. If necessary, the mix composition should then be adjusted.

1- The cement/powder ratio and the water/powder ratio adjusted depending on the flow test and other properties of the paste.

2- A different types of powder used (if possible).

3- Adjust the proportions of the fine aggregate and the dosage of superplasticizer.

4- Viscosity modifying agent used to reduce the sensitivity of the mix.

5- Adjust the grading and/or proportion of the coarse aggregate.

\section{CONCLUSIONS}

By reviewing the previous studies in the field of self compacting concrete mix design, it can be concluded that there is no standard method for designing SCC and all methods mentioned are hypotheses based on the properties of this type of concrete.

The specialty of this type of concrete makes it difficult to design the mixtures as, in addition to the required strength, there are some additional properties required like flowability, passing ability and no segregation, this leads to the need to make multiple trial mixes. This type of concrete contains powder materials and needs superplasticizer, in addition to the main components of traditional concrete from cement, fine aggregate, coarse aggregate, and water. The variety of types of superplasticizer, types of powder materials, and their different properties directly affect the design of the self compacting concrete mixtures.

From all previous studies, it can be concluded that the typical range of components in SCC by weight and by volume is:

1. The Powder content is $(380-600) \mathrm{kg} / \mathrm{m}^{3}$.

2. The paste content is $(300-380) \mathrm{kg} / \mathrm{m}^{3}$.

3. The water content is $(150-210) \mathrm{kg} / \mathrm{m}^{3}$.

4. The corase aggregate content is (7501000) $\mathrm{kg} / \mathrm{m}^{3},(270-360)$ litres $/ \mathrm{m}^{3}$.

5. The fine aggregate content balances the volume of the other constituents, typically $(48-55 \%)$ of the total aggregate weight.

6. Water/Powder ratio by Vol. is (0.85 1.10) litres $/ \mathrm{m}^{3}$.

These ratios are by no means limitation, and there are many SCC mixtures outside them.

\section{REFERENCES}

[1] Ozawa K., Maekawa K., and Okamura H., "Development of the high-performance concrete", Proceedings of JSI, 11, 1, p. 699-704, 1989.

[2] Al-Jubory Nuha H., " Effect Of W/Cm Ratio And Superplasticiser Dosages On Stablity And Flowablity Of Self-Compacting Concrete", $A L$ Rafdain Engineering Journal, Vol. 17 Issue: 1, pp. 60-70, 2009.

[3] Okamura H., "Self-compacting high-performance concrete", ConcrInt DesConstr, 19:50-54, 1997.

[4] Okamura H, Ouchi M., "Self-compacting concrete: Development, present use and future in self compacting concrete", Proceedings of the First International RILEM Symposium. Cachan Cedex, France: RILEM publications, p. 3$14,1999$.

[5] Al-Feel J. R. and Al-Saffar N. S., " Properties of Self Compacting Concrete at Different Curing Condition and their Comparison with properties of 
Normal Concrete", AL-Rafdain Engineering Journal, Vol. 17 Issue: 3, pp. 30-38, 2009.

[6] Kumar V., "Study of Mix Design of Self Compacting Concrete", International Research Journal of Engineering and Technology (IRJET) Volume: 02, Issue: 05 , Aug-2015

[7] Khayat KH, Ghezal A, Hadriche MS., "Factorial design model for proportioning self-consolidating concrete", Mater Struct.,32:679-686, 1999.

[8] Saak AW, Jennings HM, Shah SP., "New methodology for designing self-compacting concrete", ACI Mater J.,98:429-439, 2001.

[9] Al-Luhybi Ashtar S., " The Effect Of A Variable Percentage Of Limestone Filler On Some Mechanical Properties Of Self-Compacting Concrete", AL-Rafdain Engineering Journal, Vol. 17 Issue: 5, pp. 44-58, 2009.

[10] Khaleel OR, Razak RA., "Mix design method for self compacting metakaolin concrete with different properties of coarse aggregate", Mater, 53:691700, Des. 2014.

[11] Hu J, Wang K., "Effect of coarse aggregate characteristics on concrete rheology", Construct Build Mater, 25:1196-1204, 2011.

[12] Wang X, Wang K, Taylor P, Morcous G., "Assessing particle packing based selfconsolidating concrete mix design method", Construct Build Mater, 70:439-452, 2014.

[13] Okamura H, Ozawa K., "Mix design for selfcompacting concrete", Concr Lib JSCE., 25:107120, 1995.

[14] Domone P, Chai H, Jin J., "Optimum mix proportioning of self-compacting concrete", Proceedings of the International Conference on Innovation of Concrete Structures: Design and Construction. London, UK: Thomas Telford, p. 277-285, 1999.

[15] Bui VK, Akkaya Y, Shah SP., "Rheological model for self-consolidating concrete", ACI Mater J., 99:549-559, 2002.

[16] Edamatsu Y, Sugamata T, Ouchi M., "A mixdesign method for self-compacting concrete based on mortar flow and funnel tests", International RILEM Symposium on Self-Compacting Concrete. Reykjavik, Iceland: RILEM Publications SARL, p. 345-354, 2003.

[17] Su N, Miao B., "A new method for the mix design of medium strength flowing concrete with low cement content", CemConcr Compos., 25: 215222, 2003.

[18] Hwang C, Hung M., "Durability design and performance of self-consolidating lightweight concrete", Construct Build Mater.,19: 619-626, 2005.

[19] Aggarwal P., Siddique R., Aggarwal Y., Gupta S. M., "Self-Compacting Concrete - Procedure for Mix Design", Leonardo Electronic Journal of Practices and Technologies ISSN 1583-1078 Issue 12, p. 15-24, January-June 2008.

[20] Domone P., "Proportioning of self-compacting concrete-The UCL method", London, UK: Department of Civil, Environmental and Geomatic Engineering, University College London. 2009.
[21] Kheder GF, Al-Jadiri RS. New method for proportioning self-consolidating concrete based on compressive strength requirements. ACI Mater J. 2010; 701:490-497.

[22] ACI 211.1. In: Committee A, editor., "Standard practice for selecting proportions for normal, heavyweight and mass concrete", (ACI 211.1-91). Denver, USA: American Concrete Institute, p. 33, 1991.

[23] EFNARC., "Specification and guidelines for selfcompacting concrete", Surrey GU9 7EN, UK: EFNARC, 2002.

[24] Dinakar P., "Design of self-compacting concrete with fly ash", Mag Concr Res, 64(5):401-9, 2012.

[25] Jawahar J. G., Sashidhar C., Reddy I. V. R., and Peter J. A., "A Simple Tool for Self Compacting Concrete Mix Design", International Journal of Advances in Engineering \& Technology, OIJAET, Vol. 3, Issue 2, pp. 550-558, May 2012.

[26] Dinakar P, Sethy KP, Sahoo UC., "Design of selfcompacting concrete with ground granulated blast furnace slag", Mater ,43:161-169, Des. 2013.

[27] Deeb R, Karihaloo BL., "Mix proportioning of self-compacting normal and high-strength concretes", Mag Concr Res.,65:546-556, 2013.

[28] Kanadasan J, Razak HA., "Mix design for selfcompacting palm oil clinker concrete based on particle packing", Mater, 56:9-19, Des. 2014.

[29] Dinakar P., Manu S.N., "Concrete mix design for high strength self-compacting concrete using metakaolin", Materials and Design 60, 661-668, 2014.

[30] DIN 1045 “'Beton und Stahlbeton”. Beton Verlag GMBH. Koln; Germany, 1988.

[31] Kumar V., "Study of Mix Design of Self Compacting Concrete", International Research Journal of Engineering and Technology (IRJET) Volume: 02 Issue: 05, pp 1076-1078, Aug-2015.

[32] Ahlawat S., Jain U., Kundu S, "Design Mix - Self Compacting Concrete", International Journal of Engineering Science Invention Research \& Development; Vol. I Issue X , pp364-369, April 2015.

[33] Indu D., Elangovan R., "Optimum Mix Proportioning of High Strength Self Compacting Concrete", International Journal of Engineering Trends and Technology (IJETT), Volume 37 Number 6, Pp342-349, July 2016.

[34] Dhaheer MA, Al-Rubaye MM, Alyhya WS, Karihaloo BL, Kulasegaram S., "Proportioning of self-compacting concrete mixes based on target plastic viscosity and compressive strength: Mix design procedure", J Sustain Cem Mater., 5:199216, 2016.

[35] Thejas C. M., Manjunath J., Shruthi L., "Optimization of Mix Design of Self-Compacting Concrete Using MATLAB", IJRET: International Journal of Research in Engineering and Technology eISSN: 2319-116, pISSN: 2321-7308, Volume: 06 Special Issue: 05 , NCACE 2017, pp20-26, Sep-2017.

[36] Ismail I., and Shahidan S., "A Preliminary Modified Volumetric Mix Design for Self- 
Compacting Concrete (SCC) by Utilizing Asphalt Dust Waste (ADW)", MATEC Web of Conferences 103, 01008 (2017)

[37] Basu P., Gupta R. C., Agrawal V., "Mix design of self-compacting concrete - A new approach", Leonardo Electronic Journal of Practices and Technologies ISSN 1583-1078 Issue 33, p. 15-38, July-December 2018.
[38] IS 10262-2004, "Recommended guidelines for concrete mix design", Bureau of Indian Standards, New Delhi, India.

[39] IS 456-2000, "Code of practice for plain and reinforced concrete", Bureau of Indian Standards, New Delhi, India.

\section{تصميم الخلطات للخرسانة ذاتية الرص - مراجعة ـ}

رؤى سهيل زيدان

rouasuhail@uomosul.edu.iq
تقى وليا (حمد

new.matrix242@uomosul.edu.iq nuhahameedi.nh@uomosul.edu.iq

جامعة الموصل ـ كلية الهندسة ـ قسم الهندسة المدنية

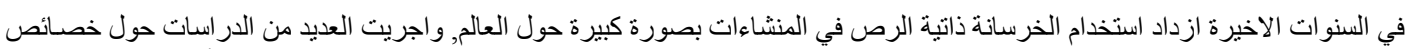

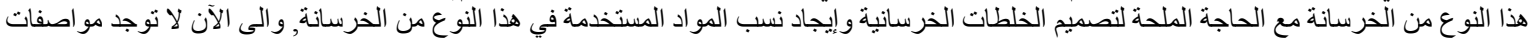

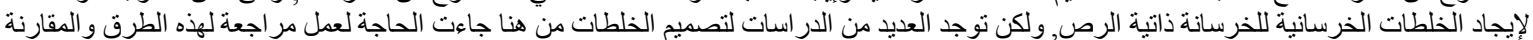

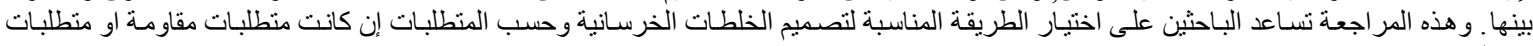
تشغيلية.

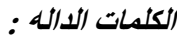
الخرسانة ذاتية الزص, تصميج الخلطات, متطلبات مقاومة, متطلبات تشغيلية. 